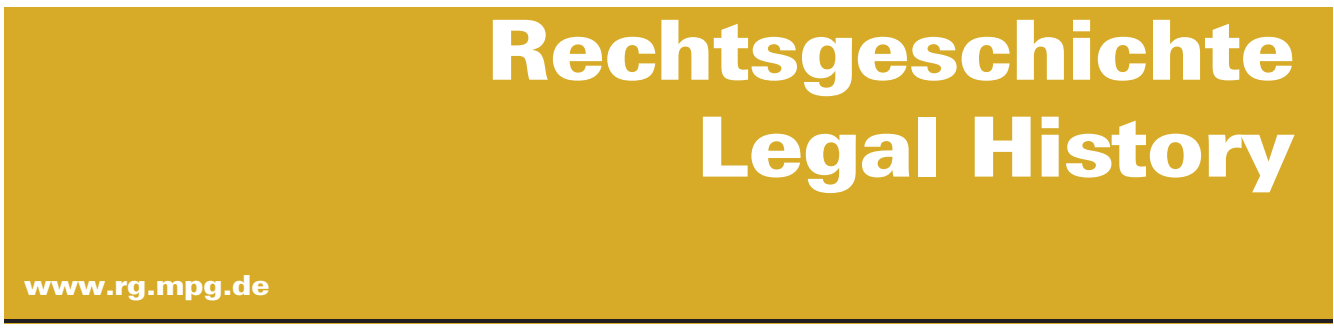

http://www.rg-rechtsgeschichte.de/rg22

$\mathrm{Rg} 222014 \quad 176-190$

Zitiervorschlag: Rechtsgeschichte - Legal History Rg 22 (2014)

http://dx.doi.org/10.12946/rg22/176-190

\title{
Zhang Zhongqiu
}

\section{China's Selection of Foreign Laws for Succession in the Late Qing Dynasty}




\begin{abstract}
This article studies the selection of a target country for succession of foreign laws by China of the late Qing Dynasty as well as the channels and approaches based on documentation in the Chinese language. According to this article, the selection was mostly limited by information, the national situation and political system, objectives, international environment, legal tradition as well as human and material resources, of which the national situation, political system and objectives serve as key factors. In this case, historically, China of the late Qing Dynasty looked at the United States, Britain, France and Germany before settling on Japan as the target country for the succession of foreign laws; and with respect to the channels and approaches for the succession, several relatively effective channels and approaches, such as studying aboard, translating foreign texts, making survey trips and hiring foreign experts, were employed. Such selection by China of the late Qing Dynasty for the purpose of succession of foreign laws provide us with useful references for thinking about law succession and the current exchange of laws and cultures between China and foreign countries.
\end{abstract}




\section{Zhang Zhongqiu* China's Selection of Foreign Laws for Succession in the Late Qing Dynasty}

Which law would people, relying on their own experience and reason, select for succession from the diversified legal world and different forms of law under specific circumstances, and what approaches would people take to accomplish such selection? These are problems that must be faced in the succession of laws. Although the analysis of and solutions to these problems are finally manifested through actions, one can get a glimpse of certain cultural and social characteristics in the succession of laws through the actions and processes. These characteristics may not be apparent, but they always influence or even dominate the selections in the succession of laws.

I. Selection of the Target Country for the Succession of Foreign Laws by China of the Late Qing Dynasty

Time and space are of great importance to our understanding of problems. China of the late Qing Dynasty in the $19^{\text {th }}$ century had been integrated into the world system led by the Western world, just as Liang Qichao said, China was no longer a country of China or of Asia, but a country of the world. Facing the whole world and featured foreign laws, China of the late Qing Dynasty indeed had a large variety of target countries for the succession. However, particularly because of the wide range of countries on hand, the selection lasted for quite a long period of time. As is wellknown, the gap between China and the West manifested itself during the Opium War in 1840, and the Chinese far-sighted personage started realizing the necessity for learning from the West. So, Wei Yuan put forth an idea of »learning from the foreign countries." Lin Zexu was even more con- vinced of the proposal. Yan Fu translated a large quantity of foreign political and legal texts simply for this purpose. ${ }^{1}$ Until the Reform Movement of 1898, Kang Youwei clearly proposed in his written statement submitted to the emperor Guangxu of the Qing Dynasty that:

It is an extraordinary national humiliation that foreigners govern their nationals in China on their own without granting us the equal rights. They claim that it is due to the harshness of Chinese penal law and differences of legal systems. I propose that now we follow the examples of laws in Rome, Britain, the United States, Germany, France and Japan and amend our laws. The amended laws shall first be enforced in the trading ports and then in the inlands. The Westerners are all very thorough and wise with regard to civil law, commercial law, market regulations, vessel regulations, procedural law, military law and public international law. Since we can no longer close our border and market, we will have to allow all the commerce and exchange. But now there is no relevant law and the government officials and the people have nothing to abide by, this will cause various bad consequences. Besides, the new laws mentioned above are something that we have never had before and can supplement and improve our legal system under the current circumstances. Therefore, I propose that a special department be established to evaluate and adopt foreign laws and amend our laws for people to abide by. ${ }^{2}$

Judging from Kang Youwei's written statement, it was definite that he petitioned the emperor Guangxu to introduce foreign laws to eliminate

\footnotetext{
* Zhang Zhongqiu, Dr., Professor of Collaborative Innovation Center of Judicial Civilization, China; of Law at the Research Institute of Legal History, China University of Political Science and Law, Beijing, China, Tel/Fax: 0086-10-82565892; Email: nuzzq@tom.com
}

1 Records of Old Dreams of the Reform: the "Self-Reform " Movement of China a Hundred Years before Wuxu, compiled by Zhu Weizheng and Long Yingtai, selects the texts on reform by wise men including Gong Zizhen, Wei Yuan, Lin Zexu, Liang Qichao, Yan $\mathrm{Fu}$, Kang Youwei et al. These texts contain illuminating ideas and true ambitions, which will no doubt prove emotive for modern readers. See ZHU Weizheng, Long Yingtai (comp.) (2000) (all subsequent citations refer to this edition).

2 Kang Youwei (1998), first volume, 214-215. 
the national humiliation. However, for the foreign country from which a law was going to be introduced, Kang mentioned Rome, Britain, the United States, Germany, France and Japan, and then said, "The Westerners are all very thorough and wise." This reveals that Kang Youwei could neither distinguish the past from the present, nor distinguish Britain, the United States, France and Germany from Japan, referring to an Eastern country as though it were a Western country and putting emphasis on the West in terms of the target country for the introduction of foreign laws. This was a normal phenomenon at that time. Although Kang Youwei's proposal was fine in theory, which was the so-called broadening of one's horizons and choosing and following the best, it was impractical. Not to mention that so many target countries could not be selected simultaneously, the two different Anglo-American legal systems and civil law system were then difficult to be concurrently introduced and integrated. ${ }^{3}$ As a result of the failure of the Reform Movement, this proposal was never put into practice.

Based on the records of the Manuscript of the History of the Qing Dynasty - Treatise on Penal Law, until 1900 when the Eight-Power Allied Forces marched into Beijing, the Qing government still intended to »introduce laws from Europe or the United States « in terms of introducing foreign laws. In 1902, the Zhili district governor Yuan Shikai, the Liangjiang district governor Liu Kunyi and the Huguang district governor Zhang Zhidong jointly advised Shen Jiaben and Wu Tingfang to act as the secretaries in charge of law amending, putting forward a point of view on law amending based on "adopting laws of the East and the West." The Qing government »issued an imperial decree as per the presented request, " and determined the guideline of »consulting laws of other countries and making an appropriate draft to achieve adaptability to both domestic and foreign circumstances and to benefit the ruling of the Qing government. ${ }^{4}$ After accepting the commission to undertake the amendment of law under the imperial order, Shen Jiaben and Wu Tingfang submitted a Memorial of Abolition of Severe Punishment in the Penal Law to the emperor Guangxu on April 24, 1905 stating that:

We admire very much Your Majesty's great and far-sighted strategy, and we will consider and draft the general approaches to implement this strategy. We propose that the government should select the officials who are familiar with the Chinese and Western laws and commission them to respectively codify the laws, hire doctors and lawyers who were versed in law from Eastern and Western countries as consultants, and assemble graduates who have studied abroad to translate the foreign laws into Chinese. We petition that a special fund be appropriated for the above-mentioned work and to carve seals in witness whereof. ${ }^{5}$

Based on the above-mentioned clues, just roughly counting the years, we can find that it took more than half a century for China of the late Qing Dynasty to select a target country for the succession of foreign laws. The trail of this process is as clear as follows: »Learning from the West« (in
3 Britain and the United States are Anglo-American law countries with case law systems following the principle of stare decisis, while France and Germany are civil law countries with statute law systems originating from Rome. These two legal systems had developed independently since ancient times and have interacted with each other since modern era, but their basic legal patterns are even now extremely difficult to integrate, let alone by China of the late Qing Dynasty.

4 The original text of Manuscript of the History of Qing Dynasty - Treatise on Penal Law is: "Until the $26^{\text {th }}$ year of the Guangxu Period (1900), the Allied Forces marched into Beijing and the emperor and his mother went hunting to the West. The personage concerned about the country all believed that then China would not become strong without introducing a law from Europe or the United States. Therefore, those present written representations on current affairs all talked a little about the penal codes. In the $28^{\text {th }}$ year of the Guangxu Period (1902), the district governor Yuan Shikai, the Liangjiang district governor Liu Kunyi and the $\mathrm{Hu}-$ guang district governor Zhang Zhidong jointly recommended Shen Jiaben, then Zuoshilang of the Ministry of Punishment, and Wu Tingfang, a secretary acting as envoy to the
United States to amend the law based on the adoption of Eastern and Western laws. The emperor issued an imperial decree as per the presented request, ordering the amendment of existing laws in accordance with the negotiated position, to consult laws of other countries and to make an appropriate draft in order to achieve adaptability to both domestic and foreign circumstances and benefit the ruling of the Qing government. Those discussing laws thereafter all paid attention to the consular jurisdiction.«

5 Shen Jiaben, Corpus of Ji Yi, Volume 1, Memorial on Abolition of Severe Punishment in the Penal Law. 
1842 / proposed by Wei Yuan, et al.); »Westerners are all very thorough and wise « (in 1898 / proposed by Kang Youwei); »Introducing a law from Europe or the United States" (in 1900/Manuscript of the History of Qing Dynasty - Treatise on Penal Law); "Adopting laws from both East and West and consulting laws of other countries" and »issuing an imperial decree as per the presented request " (in 1902 / proposed by Yuan Shikai, et al., approved by the Qing government); »The government should hire doctors and lawyers who were versed in law from Eastern and Eastern countries« (in 1905/ proposed by Shen Jiaben and Wu Tingfang with the Law Amending Council). The 63 years from 1842 to 1905 was a period of selection by China of the late Qing Dynasty from »learning from the West « to "political reform and amending laws." There is no doubt that "hiring doctors and lawyers who were versed in law from Eastern and Western countries as consultants « was one of the measures of the law amending at that time. However, based on relevant data, actually the experts of law hired by the Qing government were all Japanese. Whether the Qing Dynasty did not or could not hire Western legal experts needs to be further researched, but we can also see from this fact the importance of the Japanese element in the introduction of legal culture in the late Qing Dynasty.

Making a shift from the Western countries such as Britain, the United States, France and Germany to the Eastern country of Japan was decided by China of the late Qing Dynasty based on a careful survey and comparison. Based on relevant records, ZaiZe, Duan Fang, et al. traveled first to the United States and Britain in order to carry out political surveys, which was quite natural at that time. First, the United States and Britain were of the same system; second, Britain, the then hegemony in the world and the leading power that invaded China, was involved in a series of incidents against China initiated by the Opium War, which directly caused China of the late Qing Dynasty to despise yet admire Britain's strong national power and superior system. However, after the field trips to Britain and the United States in 1906, the government officials found that although the systems of both the United States and Britain were good, the political situation in both differed from that of China of the late Qing Dynasty. Dai Hongci and Duan Fang et al. stated in the survey report of the United States submitted to the emperor of the Qing Dynasty that, "Generally speaking, the United States is a nation founded on industry and commerce which purely upholds civil rights. The political regime of the United States is different from that of China. ${ }^{6}$ ZaiZe et al. who traveled to Britain reported that: "We have found that Britain is the European country with the most outstanding culture, but its political system is largely different from the Eastern countries. Its establishment of offices and assigning authority are quite complicated and entrenched, and are clearly not suitable for the Chinese political regime. Therefore, the government should make choices as to rejecting the dross and adopting the fine essence thereof. ${ }^{7}$ We can tell from the relevant contents of these two reports that, the political situation of either the United States and Britain differed from that of China of the late Qing Dynasty, in terms of, first, purely upholding civil rights, and second, the decentralized system with establishment of offices and assigning authority. This judgment was seemingly objective and correct. However, the crux of the issue is that the Manchu absolute monarchy was at odds with the democratic government of both the United States and Britain.

The reports submitted by the government officials conducting the surveys after visits to continental European countries including France and Germany as well as trips to Britain and the United States revealed a purpose different from any that had existed before. The report about France stated that: "We have found that France is a democratic European country. After we arrived in the capital of France, we, together with the attendants, took a detailed visit to its executive government offices. We later knew that although the system upon which France was founded is known as democratic, the rein is indeed similar to that of the empire. The laws and regulations of France are perfect, logical and in good order. Particularly, the spirit of French laws and regulations are about consolidation and circulation. We propose that the

6 Records and Historical Materials (1979), first volume, 7.

7 Records and Historical Materials (1979), first volume, 10-11. 
government reject the dross and assimilate the fine essence of the laws and regulations of France, and there should be indeed a lot that the government can select and adopt. ${ }^{\mathbf{8}}$ Dai Hongci et al., reporting on Germany, noted that: "We have found that Germany established its dominance through its mighty power. In less than a hundred years, Germany became well known in Europe for the strength of its land force. We also observed that the customs and people of Germany are diligent, thrifty and simple, which are most similar to that of China. The advantages of Germany are that politics does not hindering the people's sense of national prestige, and its people have a sense of independence; therefore, rapid progress was made. Consequently, Japan learned everything it could from Germany since the Japanese Reform for thirty years and grew vigorously. China recently often admires Japan's power without realizing that it originated from learning from Germany. "9 The reports submitted by the government officials making surveys clearly showed that, compared with the United States and Britain, France and Germany was more similar to China simply because »The rein is indeed similar to that of the empire « and there was »No politics hindering the people with national prestige. «More explicitly, the difference of mode between monarchical power and civil rights and the difference between centralization of power and decentralization of power still served as the criteria for the selection. However, it is said that the reasons the laws of France and Germany were not selected finally were that the laws of France were too perfect and the laws of Germany were too profound, which were at odds with China's actual conditions at the time, that the legal reform had just started and that the Chinese legal cultural tradition of succinctness.

Based on a round of surveys and comparisons of the world powers, the officials reached an agreement that China should learn from Japan in terms of political reform and law amending to realize the objective of absorbing the essence of Western politics and law via Japan. In fact, Huang Zunxian had put forward the idea of learning from Japan as early as in 1890. But his idea did not attract much attention at that time and therefore could not possibly become the mainstream opinion. A further reason is, for thousands of years China had regarded itself as the center of world civilization. With the exception of the spread of Buddhism in China, the massive Chinese and foreign cultural exchange was basically a unilateral export and consequently China had always treated Japan with contempt. ${ }^{10}$ Furthermore, the Chinese personages held a vague and incorrect understanding of Japan. Huang Zunxian once stated in his Preface of the Records of Japan that: "According to my observation, the Japanese personages are able to discuss Chinese books and observe Chinese events. On the contrary, the Chinese personages are obsessed about the argumentation in ancient Chinese books, are content to seclude themselves and refuse to pay attention to foreign affairs. Western countries aside, even Japan which is separated from China only by a strip of water, where the sound of night watches in China can be heard, and which can be reached within one day, is seen by the Chinese personages as one of the Three Legendary Mountains which is within sight but beyond reach.
8 Records and Historical Materials (1979), first volume, 14-15.

9 Records and Historical Materials (1979), first volume, 9-10.

10 Ancient China referred to Japan as »Wo« with contempt. See also [Japan] KimiYa Yasuhiko (1980) 55. In the late Qing Dynasty, Huang Zunxian wrote in Records of Japan - Preface of Records of Neighboring Country that: „Japan has admired China since medieval times and has sent lots of envoys to China. Japan learned the order of nature, geography, bureaucratic establishment, military equipment, national decrees and regulations, spoken and written languages, and even as small as food and drink, treasures and games, all from the Tang Dynasty. Since modern times, Japan began to associate with European countries and the United States, sending ambassadors thereto, and also learned the order of nature, geography, bureaucratic establishment, military equipment, national decrees and regulations, spoken and written languages, and even as small as food and drink, treasures and games, all from the West.« But before the SinoJapanese War of 1984 and RussoJapanese War (1904-1905), Chinese people still had traditional perception of Japan, there were very few people who had the same insight as Huang Zunxian. 
This is like Zou Yan taking the Nine as something outside the universe which is so absurd that it is not worth talking about, this is nothing but narrow-mindedness! « ${ }^{\mathbf{1 1}}$ However, the Sino-Japanese War of 1894 not only severely dampened China's sense of self-respect and arrogance in East Asia, but also threw the Chinese government and the public into a period of crisis. It was not until then that Huang Zunxian's The Records of Japan drew attention. For example, Huang Zunxian's theory of political reform and modernization following the lead of Japan exerted significant influence on reformists such as Kang Youwei and Liang Qichao et al. in terms of information and thoughts. ${ }^{\mathbf{1 2}}$ Kang Youwei once wrote in the Preface of the Records of Japanese Bibliography that: »Russia and Japan are the only two countries that grow powerful quickly due to political reform in the world. Russia is far from China and the results of its administration are not written because its languages are different from the Chinese languages. If China now learns the methods and sequences of the political reform from Japan, which is very close to China, then good results could be achieved within three years, which would be very quick. Furthermore, the Japanese languages are similar to Chinese languages, except for kana characters $(30 \%)$ that do not have many meanings. The Japanese have translated some of the essence of Western books and we can take advantage of these translated works due to Japan's success ... « This statement shows the »theory of Japan as a model country« in Kang Youwei's thoughts and also reflects the embryo of the later concept of learning from Japan which views Japanese learning as a shortcut to Western learning. Unfortunately, the failure of Wuxu Reform Movement somewhat discredited the theory of Japan as a model country, but Japan's power and China's domestic dilemma forced some of the secretaries of the Qing government to bring it up again two years later. ${ }^{13}$ In the $27^{\text {th }}$ year of the Guangxu Period (1901), the Liangjiang Governor Liu Kunyi and the Huguang Governor Zhang Zhidong jointly submitted the Three Memorials on the Political Reform to the imperial court, putting forward specific strategies for conducting political reform and law amending following the lead of Japan. On February 23 of the $27^{\text {th }}$ year of the Guangxu Period (1901), Yuan Shikai, Zhang Zhidong and Liu Kunyi again jointly recommended that Shen Jiaben and Wu Tingfang lead the Law Amending Council under the imperial decree, which stated that:

We have found that Shen Jiaben, the Zuoshilang of the Ministry of Punishment, has worked in the Ministry of Punishment for a long time and has a mastery of the criminal law. Shen Jiaben, a fourth-ranking government official and an envoy to the United States, practices foreign affairs and is an expert in Western laws. We petition that they should be selected and ordered to establish the Law Amending Council in Beijing and act as chief editors. They should be charged with the task of selecting officials as editors, proofreads and revisers. And Wu Tingfang could select two or three Western lawyers to come to China, who would also bring their associates. In recent years, the Japanese science of law has been classified into different subjects, of which the study and research are also profound. In particular, Japanese civil law is admired most deeply by Westerners. Japan is a country, which has the same culture as China. Lots of Japanese doctors of law can read Chinese statutes and records of laws and systems of
11 Huang Zunxian (2006) 4. And one paragraph commenting on the SinoJapanese War of 1984 in Story of Li Hongzhang Visiting Europe and the United States recounted the following: "I remember that prior to the Sino-Japanese war, China had great fame and grand power, all better than those of Japan; it was estimated that China would probably win this war. However, as soon as the war began, the fame of China came to nothing and the new recruits, new vessels and new weapons of China were all lost. Putting oneself in the position of

\author{
China would find it was too much to \\ bear. Moreover, Chinese people al- \\ ways looked down upon Japan and \\ viewed the three islands as not worthy \\ of putting down; but now it was \\ beaten by the country that had always \\ been despised by it. China always \\ took itself to be more powerful than \\ Japan, instead was defeated by Japan. \\ Wouldn't China be more embarrass- \\ ed? Did China also know that malady \\ could be hidden for twenty years and \\ would break out overnight? China \\ had adhered to the old habits without \\ knowing it, and had been superficial
}

and arrogant. When encountered with a vigorous new country, China would be defeated." Erkang et al. (1986) 189.

12 Yan Shaodang, Minamoto Kyōen (eds.) (1996) 412-418.

13 On February 2 of the $27^{\text {th }}$ year of the Guangxu Period (1901), the secretaries including Yi Kuang and Rong Lu jointly submitted memorials. See also Lufu Records of the Office of Grand Council of State, archived in the First Historical Archives of China, volume 7227, No. 40 Memorial Petitioning for Law Amending by Yi Kuang et al. 
dynasty. Furthermore, the local customs and practices of Japan are similar to those of China, making it easy to learn from Japan. The government can also ask the secretaries acting as envoys in Japan to seek Japanese doctors of law and select one specializing in civil law and one specializing in criminal law, and invite them to come to China to assist us with our codification and translation efforts. In this way, scope will be established, tasks will be assigned and the personnel will follow orders, making it easy to conduct the law amending. After the Law Amending Council has been established, the important provisions of the laws in urgent need of amendment should be translated and revised, and the amended laws will be promptly presented to the emperor for review and finally announced to have taken effect. The law amending will be conducted gradually in order to achieve perfection. ${ }^{\mathbf{1 4}}$

One month later, i. e., April 6 of the $28^{\text {th }}$ year of the Guangxu Period (1902), the Qing government issued an imperial decree that $\gg$ As now there are various affairs about commerce and negotiation, Shen Jiaben and Wu Tingfang are hereby ordered to amend all the current laws in accordance with the negotiation situation, to consult laws of other countries, to conduct careful textual research and correction, and to compile an appropriate draft in order to achieve adaptability to both domestic and foreign circumstances and benefit the ruling of the Qing government. After the amended laws are presented for imperial review, an imperial order will be issued to promulgate these amended laws. " ${ }^{15}$ Henceforth, Shen Jiaben and Wu Tingfang assumed the most important mission of their times and went up onto the law amending stage. In the $30^{\text {th }}$ year of the Guangxu Period (1904), the two secretaries in charge of law amending brought up the same suggestion again, emphasizing that Japan »became a model of political reform via learning from the strengths of several other countries. China and Japan are of the same culture; therefore China should take Japan as standard. « ${ }^{\mathbf{1 6}}$ In May of the same year, the Qing government established the Law Amending Council, officially starting the succession of modern Japanese law by China of the late Qing Dynasty.

When we again consider why the Qing government finally selected Japan as the target country for succession of foreign laws, the causes were very complicated. However, the most direct reason was to revoke consular jurisdiction following Japan's lead. In 1853, Western powers forced Japan to open up its borders. In 1858, the Japanese shogunate was pressed by the United States into signing with it The Treaty of Amity and Commerce, and later the same treaty with the Netherlands, Russia, Britain and France, which were known as the »Ansei Five-Power Treaties. " ${ }^{\mathbf{1 7}}$ The aforesaid treaties granted the five powers privileges including consular jurisdiction in Japan. Japan felt humiliated by this, and revoked the consular jurisdiction after many years of effort, in particular by building modern legal systems following the example of Western countries, which shook up and inspired the Qing government to a great extent. On February 2 of the $27^{\text {th }}$ year of the Guangxu Period (1901), Yi Kuang and Rong Lu jointly submitted a memorial stating that:

At the beginning of the Japanese political reform, Japan dispatched officials to Western countries to learn Western laws, established the Law Council to review, approve and promulgate the amended laws. Japan gradually became more powerful over two decades. The other countries took Japanese laws to be the same as their own laws, and therefore foreigners residing in Japan were willing to be bound by the Japanese laws. Consequently, Japan was able to exercise jurisdiction by itself, which is the clear evidence of the effects of law amending. ${ }^{\mathbf{1 8}}$

Besides, some other factors related to such opinions also promoted the choice of the Qing government. Considering the opinions at the time,
14 Liao Yizhong, Luo Zhenrong (coll.) (1987) Volume 14.

15 Zhu Shoupeng (ed.) (1958) 4864.

16 Lufu Records of the Office of Grand

Council of State, archived in the First Historical Archives of China, Volume 7227, No. 5.
17 See also Sakamoto Taro (1992) 349-354.

18 Lufu Records of the Office of Grand Council of State, archived in the First Historical Archives of China, Volume 7227, No. 40 Memorial Petitioning for Law Amending by Yi Kuang et al. 
it was mostly related to politics, education, customs, written languages, geography, as well as human and material resources. In addition, Shen Jiaben and Wu Tingfang, the secretaries in charge of law amending, stated very clearly in their jointly submitted memorial that:

The recent Meiji Reform in Japan was also based on law amending. Before new laws were promulgated, the punishment of dismemberment, beheading, registering and confiscating all the assets and tattooing had been abolished. Finally, the Japanese folk customs had changed tremendously and nation became powerful and prosperous very quickly. Today Japan is a power in East Asia. China and Japan have the same culture, education, written language ${ }^{19}$ and social customs and habits, undoubtedly China can draw on the experience of Japan. ${ }^{\mathbf{2 0}}$

Previously, Kang Youwei, Zhang Zhidong et al. advocated that Chinese personage should study in Japan. Zhang Zhidong wrote in the article Learning Tour that: »Studying in Japan for one year is superior to reading Western books for five years. In terms of the foreign country to study in, Japan is better than Western countries, as Japan is close to China and studying in Japan is not that expensive. Large numbers of personages could be dispatched to study in Japan for the following reasons: the first one is that Japan is close to China, therefore it is easy to be inspected; the second one is that Japa- nese language is similar to Chinese language, therefore it is easily understood; the third one is that Western learning is quite complicated, Japanese people have deleted or modified the unnecessary part thereof. China and Japan have similar situations and customs, so it is easy to follow the lead of Japan, through which we can get double results with half the effort. ${ }^{21}$ If we wish for refinement and perfection, we can then go directly to the Western countries to study."

The secretaries of the Qing government, such as Shen Jiaben, strongly advocated learning from Japan versus having to go one step further in order to accommodate two issues arising from »referring to the laws of other countries. "One was the severe shortage of talented people who had concurrent mastery of Chinese and Western foreign languages as well as law; the other was the difficulty in selecting the law to be introduced from so many Western legal texts. As was observed at the time, »If we wish to translate all the codes of the European countries and the United States, the difficulty of finding the translators notwithstanding, the books are so many that it is impossible to translate all of them in the first place. ${ }^{22}$ The above two issues would not arise if China selected Japan, because there were so many students studying in Japan who had concurrent mastery of the Chinese and Japanese languages as well as law. And more importantly, in the eyes of the Chinese people, Japan had already taken the best of Western laws and cultures, including finding the solution to the long-
19 With regard to the "same language" mentioned by Shen Jiaben et al. in their memorial, I have some additional remarks. In fact the Chinese languages and Japanese languages are not identical. Initially, the Japanese languages used the Chinese languages as a reference and later evolved from the Chinese languages. Japanese and Chinese languages are all ideograms, having many similarities and something in common with each other. Therefore, compared with alphabetic Western languages, Japanese languages are easy for Chinese people to learn and master. This alone effectively promoted the selection of modern Japan by China of the late Qing Dynasty. Just as Professor Reynolds said, "If China elected to rely upon different countries speaking different languages, the different ideas and doctrines would lead to confusion of concepts, ambiguity of words, heated debates, opposition and resistance. Luckily for China, it had single firsthand resources on hand, which was of the same culture and very easy to obtain. Japan provided over ten years of generous help to China during the period between 1898 and 1910 which was full of ordeals to China.» ReYNOLDS (2006) 132.

20 Shen Jiaben, Corpus of Ji Yi, Volume 1, Memorial on Abolition of Severe Punishment in the Penal Law.

21 The phrase "getting double results with half the effort " is often seen in the arguments of studying law and politics in or from Japan. For example, seen in the memorial on studying law and politics in Japan submitted by Yang Shu, Chinese minister to Japan, on January 9, 1905 (see also
Historical Materials of Negotiations between China and Japan in Guangxu Period of the Qing Dynasty, Volume 68, page 35 / total page no. 1317); seen also in the memorial on law amending following the lead of Japan submitted by Wu Tingfang et al. on October 15, 1905 (see also Records of Imperial Government in Guangxu Period, fifth book, page 5431).

22 Shen Jiaben, Corpus of Ji Yi, Volume 6, Preface of a Complete Collection of New-Translated Laws and Regulations. 
term headache facing the Chinese people, i. e., the translation of legal terms. ${ }^{23}$ Shen Jiaben once pointed out on this issue that: "Japan's old laws were mostly the laws of the Tang Dynasty. Japan adopted Europeans laws within decades after Meiji and had become a power, which would have been impossible to achieve if Japan had just admired the forms of European laws. The Japanese emperor and the subjects put their heart and soul into the same cause, worked hard and aimed high, spared no financial resources to translate and edit Western books in order to study Western learning and rejected the dross and adopted the fine essence thereof. They dedicated their entire nation's attention to their laws and therefore their national power is getting stronger and stronger. All of this did not happen by chance. ${ }^{24}$

The "amending of law « in the late Qing Dynasty was the requirement and reflection of the "political reform « that was taking place in the country at the time. The core of the political reform was to maintain the survival of Qing government (which was suffering from the domestic unrest and foreign invasion) during the reformation. Thus, following Japan to practice »constitutional governance, «i. e., autocracy disguised in constitutionalism, was the best choice. This was clearly stated in the secret memorials submitted by the secretaries conducting surveys such as ZaiZe. It was stated in the secret memorials that:

Last time when I was back in Beijing, I submitted a memorial petitioning that constitutional governance should be practiced to reassure the public and maintain the national power
... Judging from the Japanese constitution, evidenced by what Marquis Itoh and Dr. Hozumi said, the monarch has seventeen powers ... Speaking from today's circumstances, constitutionalism has three most important benefits, i. e., perpetuation of the imperial throne, gradual reduction of foreign aggression and putting down civil strife $\ldots{ }^{25}$

Chen Zhaokui, the chief of staff of the Ministry of Finance of the Qing government, stated more bluntly in the Memorial on Six Strategies on Establishment of Law Council and Codification of Laws and Regulations: »Therefore, the Japanese constitutionalism, nominally derived from Britain and the United States etc., in fact took the Japanese historical and social situations as criteria. As the politics and laws of Britain were built gradually, those of France were a result of autocracy, those of the United States and Germany were built on republicanism, only those of Japan were a result of honoring the emperor. Consequently, the laws of the above countries have lots of discrepancies. As China has the same culture and a similar purpose of maintaining the empire as Japan, China should therefore learn from Japanese constitutionalism. ${ }^{26}$ The selection of the political system fundamentally determined the selection of the law amending. Accordingly, political factors played a vital role in the shift of China of the late Qing Dynasty from "consulting laws of countries« to Japan in terms of introducing foreign laws.

Besides, modern Japan's attention and support also aided the political reform and law amending of China of the late Qing Dynasty. Japan was the
23 »This factor was often ignored, but both reformist and revolutionist all relied on it completely. Every effort of China to translate Western concepts, words and phrases into Chinese locution failed, ranging from the crude translations in the 1830 s and 1840 s by Lin Zexu (1785-1850) and Wei Yuan (1794-1856), to the various discordant new words created by Western missionaries during their translations, and down to the rather elegant but equally ineffective creation by Yan $\mathrm{Fu}$ at the turn of the century. The Chinese characters of modern Japanese vocabulary used during the Meiji era had been completely standardized in 1890 s, being functionally cohe- rent. Without this vocabulary, any effects of China would be defeated in the war and quarrel of words and phrases." (ReYnolds [2006] 195). Professor Reynolds overstates it a lit tle when saying that the reform by China of the late Qing Dynasty »would be defeated, « but Japan’s successful translation of Western legal terms using Chinese characters did facilitate to a great extent the succession of Japanized Western legal culture by China.

24 Shen Jiaben, Corpus of Ji Yi, Volume 6 , Preface of a Complete Collection of New-Translated Laws and Regulations.
25 See also Records and Historical Materials (1979), first volume, 174.

26 See also Records and Historical Materials (1979), first volume, 264-265. 
power that was most active in China's political reform and law amending at that time. There are various reasons for this. For example, one reason is paying a debt of gratitude to Chinese culture since the Tang Dynasty; ${ }^{27}$ and another is a strategic plan to disseminate Japan's successful experience in China, to significantly cultivate pro-Japan forces, and to realize a dream of building a greater Far East led by Japan. Take Yano Fumio, the Japanese plenipotentiary ambassador to China from March 1897 to December 1899, as an example, he once orally presented and wrote letters to Chinese officials that the Japanese government had undertaken to bear the costs of two hundred Chinese students studying in Japan. He wrote about it in the secret letter to Japanese Foreign Minister Nishino Jiro that:

To spread the new Chinese talents influenced by Japan in the old empire is the best strategy of building up Japanese influence in East Asia. Those students studying military affairs will not only follow the example of the Japanese military system, but they will also rely on Japan for military supplies. In this way, the military affairs of the Qing troops will be Japanized. Those students studying science will surely have a close relationship with Japan due to their jobs, which will expand Japanese industry and commerce in China. Students who major in law and politics will surely treat Japan as the role model during China's future reform. If this is the case, then not only will the Chinese government and the public trust Japan twenty times more than before, but Japan will also be able to expand its influence immeasurably in China. ${ }^{28}$
According to Professor Reynolds, this letter is a typical example demonstrating Yano Fumio's shrewdness in terms of advancing and protecting the interests of his own nation. ${ }^{29}$ In fact, the later historical development almost corroborated Yano Fumio's letter, at least in the areas of law and politics. As stated above and below, Japan provided various forms of support to China of the late Qing Dynasty in terms of political reform and law amending ${ }^{30}$ and branded China's political reform and law amending with a deep Japanese mark, so that the modernization of Chinese law began with Japanization.

II. Selection of Channels and Approaches by China of the Late Qing Dynasty for Succession of Modern Japanese Law

After China of the late Qing Dynasty had determined the target country for succession, in terms of the channels and approaches for the succession, several fairly effective methods were adopted including studying aboard, translating foreign texts, making survey trips and hiring foreign experts. First of all, studying in Japan during the late Qing Dynasty can indeed be compared to the grand occasion of Japan dispatching envoys to the Tang Dynasty in those years. ${ }^{31}$ Slightly differently yet far better, among the Chinese students studying in Japan, quite a large group of students studied law and politics. ${ }^{32}$ There were many reasons for this. One interesting reason was that those who studied law and politics could later become government officials, which conformed to the Chinese value orientation of official standards. Of
27 For example, on October 27, 1899 , one military officer dispatched by Sichuan Province wrote in his diary after visiting the newly appointed Japanese chief of the general staff Ōyama Iwao with one peer that: »We visited the Japanese chief of the general staff Marshal Ōyama Iwao today and talked about uniting efforts today. He said with utmost modesty and sincerity that since the Tang Dynasty, Japan had learned food, drink, garment, daily life and knowledge etc. from China. Today, Japan is willing to assist China, not only because China and Japan are so closely related and share common interests, but also because Japan wants to pay a debt of gratitude.« (Quoted from a secondary source, SANetou Keishuu [1983] 115).

28 Quoted from Reynolds (2006) 32-33.

29 See also Reynolds (2006) 32.

30 Among which the crash plan of law and politics made in response to China's need for talents in law and politics had a profound influence. This plan started from the first batch of 94 students in May 1904 (of which 67 students graduated in April 1905), ended with the fifth batch of 843 students at the end of 1906 (of which 385 students graduated in April
1908). Japan dispatched the then most famous scholars as teachers, such as Me Jiro, Shida Kotaro, Okada Asataro and Oka Shigejiro. Except for Me Jiro, the other three scholars were all foreign experts hired by China of the late Qing Dynasty for law amending, who compiled almost all the draft laws proposed by the Law Amending Council. Through this plan, talents in law and politics and professional knowledge rapidly passed on to China (see also Reynolds [2006] 56-58).

31 See also Sanetou Keishuu (1983).

32 See also Wang Xiaoqiu, Oraba Shu (eds.) (1996) 323. 
course, the urgent need and practicality of law and politics at that time may be one of the reasons; especially the scholarly notion of »Every man has a duty to his country« played an important role at that time. For example, the Studying Abroad Year Book edited by the students studying in Japan cast light on the true state of mind of many students who studied in Japan in order to save China from extinction: "We traveled over a thousand miles to study in Japan, cutting through the big wind and waves on our way. We are living away from home and country, and treating the hardships we suffered as sweetness. Why are we so eager to study in Japan? When the thousands of students studying in Japan are asked about their aspirations, there is no one who does not say that we so much fear that the China's political situation is dire, that the knowledge is not acquired, that society is corrupted, that China's territory is shrinking daily and our powerful neighboring country is trespassing. We would rather sacrifice our comfort and pleasure for the moment, be conscientious and do our best, in order to get long-lasting and indefinite future happiness, which is our great wish. « 33 We can get a general idea about the specific reasons why Chinese people studied law and politics in Japan in the late Qing Dynasty and its unprecedented splendor from the research conducted by Professor Wang Jian. ${ }^{34}$

So, many talented students who studied law and politics in Japan provided a lot of intellectual support for the succession of modern Japanese law by China of the late Qing Dynasty. Translation of books was one of the direct benefits. According to statistics, from 1902 to 1904, the quantity of translated foreign books reached about 533 varieties, of which only 130 varieties in Western foreign languages came from Britain, the United States, France and Germany, accounting for 24.5\%; however, 321 varieties were translated from Japanese, accounting for $60.2 \%{ }^{35}$ From 1896 to 1911, of the 958 varieties of books translated from Japanese into Chinese, 778 varieties were related to social sciences, accounting for $81.2 \%$, of which politics and law amounted to the as many as 194 varieties. ${ }^{36}$ Professor Li Guilian's study also reveals that the Law Amending Council led by Shen Jiaben translated into a total of 103 varieties of books in four batches, of which 38 varieties of books were translated from Japanese into Chinese, accounting for about 38\% of all translated books. ${ }^{37}$ These two statistics also reveal the significance of translations in the succession of foreign laws by China of the late Qing Dynasty and the Japanese inclination thereof. Just as Shen Jiaben said, "Consulting the laws of other countries and putting the most emphasis on the translation of books. ${ }^{38}$ Apparently, the translation of Japanese legal materials was the priority in translation of books.

In the $33^{\text {rd }}$ year of the Guangxu Period (1907), the secretary in charge of law amending Shen Jiaben, also found that what was equally important in the translation of books was conducting investigations and surveys. He put forward in his memorial that:

What is equally important in the translation of books is conducting investigations. In recent years, the quantity of people studying aboard has become large, and various political and law books have been compiled and translated. Although some points in these books can be used as reference, the books on a whole either stick to one type of theory, or are not about current legal systems; therefore, none of these books could be relied upon as invariable standards. Last year I submitted a memorial recommending Dong Kang, the Houbulang of the Ministry of Punishment etc. to go to Japan to inspect its legal systems. They only investigated the Japanese sentencing and prisons before they returned to China due to insufficient funds, let alone investigate European and American legal systems. That's why more investigations should be conducted. ${ }^{39}$
33 Book of Students Studying in Japan, Tokyo Intelligence Inspiring Press, 13. Quoted from a secondary source: Wang Xiaoqiu, Oraba Shu (eds.) (1996) 317-318. Chinese students studying in Japan indeed made very important contributions to the re- form in the late Qing Dynasty, for details see also: Chinese Students Studying in Japan and the Reform in the Late Qing Dynasty (2002).

34 See also Wang Jian (2001) 76-112.

35 See also Huang FuQINg (1983), the statistics cited 183-185.
36 Wang Xiaogiu, Oraba Shu (eds.) (1996) 328.

37 See also Li Guilian (1994) 30.

38 See also Records and Historical Materials (1979), second volume, 838.

39 See also Records and Historical Materials (1979), second volume, 838 . 
The field survey of legal systems started with the survey of politics by five government officials of the Qing government. Actually, it was all inspired by Japan and proceeded to treat Japan as a role model. Therefore, as early as in the $31^{\text {st }}$ year of the Guangxu Period (1905), Shen Jiaben and Wu Tingfang had especially submitted memorials to petition for it. They held the view that "at the beginning of the Japanese law amending, Japan had dispatched officials to France, Britain and Germany several times to learn the essence of Western European legal theories and import them to Japan. Then Japan gathered together the strong points of other countries' laws and compiled its complete code. The Japanese litigation laws, its sentencing and prison regulations and penal system are all brilliant and complete. As a result, Japan is able to make all the foreigners residing in Japan willing to be bound by its laws and to exercise jurisdiction by itself. The key reason for this is that Japan has repeatedly dispatched officials to conduct surveys. ${ }^{\mathbf{4 0}}$ Therefore, in the $32^{\text {nd }}$ year of the Guangxu Period (1906), as recommended by Shen Jiaben, Dong Kang, et al. were authorized to go to Japan to make an inspection on the matters related to sentencing and prisons. ${ }^{41}$ In the first year of the Xuantong Period (1909), Li Jiaju, a high government official in charge of the inspection of constitutionalism, was also dispatched Japan to make an inspection of its judicial system. Li Jiaju suggested in his inspection report that, "China should now prepare provisional constitution making. There are several key points for this. The first one is independence of trial and decision, which should be prepared in earnest; the second one is judicial personnel, who we should train with special care; the third one is codification of the penal code, which needs to be divided into several stages; the fourth one is civil code and commercial code, for which we should investigate customs; the last one is civil procedure and criminal procedure law, which need to be codified as soon as possi- ble. ${ }^{\mathbf{4 2}}$ Judging from the historical facts, the above suggestions played a practical part in the political reform and law amending in the late Qing Dynasty, and hence we can see that investigations and surveys played an important role in the succession of modern Japanese laws by China of the late Qing Dynasty.

Another important approach for succession of modern Japanese laws by China of the late Qing Dynasty was to directly hire Japanese experts to participate in China's legislation and legal education. Under the approval of Shen Jiaben, the Japanese experts were sent to China at the time to participate in the lawmaking, including Okada Asataro, Matsuoka, Shida Kotaro and Oka Shigejiro. Okada Asataro mainly took charge of drafting the criminal law and organization law of courts, Matsuoka took charge of drafting the civil law and litigation law, Shida Kotaro took charge of drafting the commercial law and Oka Shigejiro took charge of drafting the penal law. Considering the accomplishments of law amending in the late Qing Dynasty, all foreign experts of law hired by the Qing government seemed to be Japanese and they participated in the making of almost all new laws. ${ }^{43}$ Dong Kang, who participated throughout the law amending, said that, »the Law Amending Council was established upon request after the chaos in the year of Gengzi. At first it was on the former site of the Code Council. Later it was expanded to set up a law school. Japanese doctors of law were hired to participate in the codification, including Dr. Okada, Dr. Shida and Dr. Matsuoka et al. The drafts of six major laws were all from Japanese doctors of law. « ${ }^{\mathbf{4 4}}$ The Japanese experts drafted laws for the Qing government and participated in the legislative debates following the mode of the then Japanese laws, consequently the draft laws made by the Law Amending Council of the Qing Dynasty were referred to by some people at that time as "Japanese Laws. $" 45$ The appropriateness of such reference aside, one point is clear: the
40 Quoted from Liu Junwen, IKeda ON (eds.) (1996) 203.

41 See also He Qinhua et al. (eds.) (2005) 638-699, Report on Inspection of Japanese Sentencing and Prisons.

42 See also Records and Historical Materials (1979), second volume, 879.

43 In China's modern history, besides Japanese, foreign experts from Eu- rope and the United States, such as Hart, William Alexander Parsons Martin, Padoux, Blume, Escarra, Lobingier, Goodnow and Pound et al., participated in China's law amending. But those who actually participated in the law amending seemed all to be Japanese experts in the political reform and law amending in the late Qing Dynasty. For related informa- tion, see: Western Laws Introduced into China: Foreigners and the Reform of Chinese Law in Modern Times (2001).

44 He Qinhua et al. (eds.) (2005) 469.

45 See also Li Guilian (1994) 30-32. 
effect of the Japanese factor in the primary state of the modernization of Chinese legal system does not seem to be less than the influence Tang Law exerted on Japan in those years.

When the Japanese experts were hired to participate in the lawmaking of the late Qing Dynasty, Japanese teachers were also hired to provide support for China's law education. The above-mentioned four Japanese experts were all part-time teachers at Imperial University of Peking as well as holding the position of investigators of the Law Amending Council. We can know from the List of Japanese People Hired by the Qing Empire edited by the Japanese Ministry of Foreign Affairs in 1909 that, at the time there were 405 Japanese teachers in China, of which 19 teachers were teaching law and politics, 3 teachers were teaching policing, and the other the remaining subjects 241 teachers were teaching were unspecified. The teachers teaching law and politics and policing were outnumbered only by those teaching industry (39) and science (34), and were more than those teaching other subjects. ${ }^{46}$ In this respect, we can see the deep relationship between China's modern legal education as part of the legal culture and hiring of Japanese experts.

In terms of determining the contents and sequence of selection of foreign laws for the purpose of succession, China of the late Qing Dynasty, under the stress of the circumstances, considered Western countries at first instead of Japan with a preference given to international law. Lin Zexu set a precedent. For the 20 years after the Opium War, it was still the same case. According to the data collected by later generations, over a period of over 30 years from 1861 to the eve of Wuxu Reform Movement, over 18 kinds of laws were translated, of which 8 kinds were public international laws, 3 kinds were judicial judgment laws, 3 kinds were military laws, and 4 kinds were other laws. In addition, the translation of legal treatises had not yet started. Surprisingly, none of these translated works were from Japan. ${ }^{47}$ This is enough to show that before the Wuxu Reform Movement, the Chinese people still focused on Westerns' powers and had not yet taken note of the Japanese laws. However, after the Wuxu Reform Movement (particularly the start of the political reform and law amending) China of the late Qing Dynasty had not only noted the advanced character and convenience of modern Japanese law, but also regarded the succession of Japanese law as its mission. However, facing the entirety of Japanese, in terms of selection of contents and the sequence of selection, the Qing government did not seem to have established a unified plan. Perhaps, precisely because of a process review and the result of a modern perspective, the selection seemed to have some sort of order.

According to my observation, the law, legal experts and legal doctrines were introduced almost around the same period, which should be related to the guidelines of the Law Amending Council led by Shen Jiaben on law amending. He even put forward that the translation of books, surveys and compilation were equally important and import of laws, the introduction of science of law and the hiring of experts should be carried out at the same time. ${ }^{48}$ However, in terms of the succession of law and the science of law, international law was not mentioned with preference. Instead, criminal law, administration of justice and penal law were made a priority. This is evidenced by Japanese law and legal treatises translated by the Law Amending Council, as recounted by Shen Jiaben. The translated works spanning four batches include, Japanese Current Criminal Law, Japanese Amended Criminal Law, Japanese Army Criminal Law, Japanese Criminal Procedure Law, Japanese Prison Law, Japanese Tribunal Organic Law, Lectures on Japanese Criminal Law, Japanese Criminal Law Theory, Japanese Prison Visiting Record, Japanese Draft New Criminal Law, Code Theory, Penology, On Prison Affairs, Japanese Tribunal Organization Legislative Theory, Japanese Commercial Law, Japanese Civil Law (Unfinished), Japanese Bankruptcy Law Theory by Kato Masaharu, Japanese Measures on Foreign Countries after Amendment of Treaties, Japanese Amended Criminal Procedure Law, Japanese Current Civil Procedure Law, Outlines of Nationality Law and Memorandum

46 Quoted from Wang XIaogiU, Oraba

SHu (eds.) (1996) 338.

47 See also Li Guilian (1994) 24.

48 See also Records and Historical Ma-

terials (1979), second volume,

837-839. 
by Investigator Shida Kotaro, Japanese Civil Procedure Law Annotated, Japanese Criminal Procedure Law Theory, Japanese Civil Procedure Law Outlines, Japanese Inheritance Law by Okuda Gijin, Okuda Civil Procedure Law, Japanese Law Dictionary, and the uncompleted translation work Civil Law Rational, General Principles, Right in Rem and Right in Personam written by Matsuoka Taro. We can see from these translated works that although some were on private law, such as civil law and commercial law, they were limited in quantity compared with criminal law, administration of justice, judgment and the penal law, which were public laws. Together with the fact that the draft constitution of the late Qing Dynasty was mainly based on the Meiji Constitution, ${ }^{49}$ we can gain an impression of the selection of modern Japanese legal culture for succession by China of the late Qing Dynasty in that the law, science of law and legal experts were introduced almost around the same period, that more emphasis was put on public law rather than the private law, and that the criminal law, administration of justice and the penal law were given priorities.

China of the late Qing Dynasty made such a selection for some reasons. Considering the data on hand, the most critical factor is revoking consular jurisdiction. Consular jurisdiction was originally a consequence of the excuse given by Western powers that the laws of the Qing Dynasty, i.e., criminal law, trial and penal law, were those of a barbaric and backward state. ${ }^{\mathbf{5 0}}$ So, the amending of relevant laws in this sense was directly related to the revoking of consular jurisdiction. Although this was more of an excuse for the Western powers, the Qing Dynasty, who was already in a weak position, had no choice but to take it seriously.
As Shen Jiaben quoted, referring to a Japanese legal expert's insistence on the notion that only one method of capital punishment should be reserved, »as Doctor Okada put it, a lot of countries have abolished capital punishment. Those who preserve capital punishment all adopt only one execution method. Nowadays, if China were to improve its penal law while still preserving two execution methods of capital punishment of decapitation and hanging as against the world trend, foreigners reading the amended penal law in the future would still view it as a barbaric and uncivilized law, which would definitely be a big hindrance to the reclamation of our rights and the correction of the treaties. ${ }^{51}$

Another factor related to consular jurisdiction is that the Western powers, by signing certain treaties, once sought to abandon their judicial privileges in China as soon as the reformed penal system of the Qing government had conformed to the legal norms. ${ }^{52}$ Although such treaties were later proved insincere, they nonetheless exerted influence on the Qing government's selection. According to the records of Manuscript of the History of Qing Dynasty - Treatise on Penal Law,

after the year of Geng Zi of the Guangxu Period (1900), the Western countries remade treaties and the Chinese government pushed to have the Western countries revoke such treaties; however, the ambassadors of these countries refused on the ground that the Chinese legal system was still not perfect. Only when the Chinese government forced the issue did these Western countries announce that they would agree to abandon the consular jurisdiction if the trial could be improved in the future. This announcement
49 See also Luo Zhiyuan (comp.) (1976) 137-148.

50 Shen Jiaben stated in his memorial submitted to the emperor that "we did a careful comparison between Chinese law and the laws of other countries and found that although the spirit of the laws of other countries is within the sphere of Chinese law, the penal systems and charges are different. In general, the penal laws in Western countries are usually less severe than that of China ... Therefore, Westerners often criticize the Chinese severe punishment as cruel, and the foreigners residing in China all use this as an excuse to be free from the Chinese law ... Revoking extraterritoriality in the first place is key to China's political reform and self-reliance.« (Shen Jiaben, Corpus of Ji Yi, Volume 1, Memorial on Abolition of Severe Punishment in the Penal Law.)

51 Shen Jiaben, Corpus of Ji Yi, Volume 3, Notion of Only One Execution Method for Capital Punishment.

52 In the $28^{\text {th }}$ year of the Guangxu Period (1902), the Qing government entered into the Renewed Treat of Commerce and Navigation with Britain, Article 12 of which provided that "China desires deeply to amend its laws in order to have the same laws with Western countries, Britain undertakes to use its best endeavors to assist China in this regard. Once Britain is satisfied to find that the laws and trials in China and all other matters related thereto have reached perfection, Britain is willing to renounce its extraterritoriality." (New Decrees of Guangxu Period in the Qing Dynasty, sixth book, page 18). Later, the Qing government renewed this treaty with other powers. 
was recorded in the treaties. Therefore, the Law Amending Council was established in the $28^{\text {th }}$ year of the Guangxu Period (1902) under the imperial decree "consulting laws of other countries to achieve adaptability to both domestic and foreign circumstances according to the negotiation situations " with the purpose to amend the laws in order to make the Western countries give in. Diplomacy depends on national strength, so the once lost rights cannot simply be reclaimed by words. Therefore, even though law amending has always been emphasized, it produced little effect by the time the cornerstone of a nation was damaged. The legal system should not take the blame.

If we discuss these issues further, we will find that such selection in the late Qing Dynasty also had a certain inherent connection with the tradition of Chinese legal culture. The Chinese legal culture has a long history. However, it has been basically characterized by a criminalized public law culture. The civil law and commercial law have had no corresponding basis and have been curbed by criminal law, and thus have not developed well. Thus, traditionally, China's regulation of various social relations had mostly relied on the criminal law and the criminal-law-like administrative laws and regulations, which had basically not been changed till the late Qing Dynasty. Without doubt, such a tradition of legal culture would have undoubtedly exerted influence on the selection of foreign laws by China of the late Qing Dynasty for succession. From a legal transplantation point of view, this reflects the »theory of legal culture identity, ${ }^{53}$ as coined by the Japanese jurist Professor Masaji Chiba.

\section{Bibliography}

- Chinese Students Studying in Japan and the Reform in the Late Qing Dynasty (2002), Nanchang: Jiangxi Education Press

- Erkang, CaI et al. (1986), Story of Li Hongzhang Visiting Europe and the United States, in: Towards the World Series, edited by Zhong Shume, first part, ninth book, Changsha: Yuelu Publishing House

- He Qinhua et al. (eds.) (2005), Dong Kang's Corpus of Law, Beijing: China University of Political Science and Law Press

- Huang Fuqing (1983), Students Studying in Japan in the Late Qing Dynasty, Taipei: Taiwan Central Research Institute

- Huang Zunxian (2006), The Records of Japan, punctuation collating by Wu ZHenqing et al. first volume, Tianjin: Tianjin People's Press

- Kang Youwer (1998), The Sixth Written Statement Submitted to Emperor of Qing Dynasty, in: Kang Youwer, Political Essays, edited by Tang Zhijun, Beijing: Zhonghua Book Company

- Kimiya Yasuhiko (1980), History of Japanese and Chinese Cultural Exchange (translated by Hu Xinian), Beijing: The Commercial Press

- Li Guilian (1994), The Law Reform in Modern China and the Japanese Influence, in: Research of Comparative Law

- Liao Yizhong, Luo Zhenrong (coll.) (1987), Memorials Submitted by Yuan Shikai, Tianjin: Tianjin Ancient Books Publishing House

- Liu Junwen, Ikeda On (eds.) (1996), Outline of History of Chinese and Japanese Cultural Exchange - Legal System Volume, Hangzhou: Zhejiang People's Press

- Luo Zhiyuan (comp.) (1976), Research on Modern Chinese Legal System Evolution, Taipei: Zhengzhong Book Company

- Masaji Chiba (1997), Legal Diversity: from the Japanese Legal Culture to General Theory (translated by Qiang Shigong et al.), Beijing: China University of Political Science and Law Press

53 According to Masaji Chiba, »the theory of legal culture identity maintains the identity of legal culture and also promotes the change of its constituent variables in order to adapt to constantly changing circumstances. The motivation for change may be societal, i. e., the internal activity of legal subjects (which cultivates legal culture), and may also come from external stimulation. In whichever situation, the theory of identity is presumed to provide a certain standard to legal subject, a kind of society of legal culture. This standard promotes and also limits the selection by the subject in terms of how and to what extent should the current legal system, society, legal order and legal culture be amended, replaced and preserved, in particular, how and to what extent should the legal system assimilate or reject local and extraterritorial factors" (see Masaji CHIBA [1997] 179, and above and below.) 
- Records and Historical Materials (1979): The Records and Historical Materials of the Preparation for Establishing Constitutionalism in the Late Qing Dynasty, ed. by the Archives Department of Ming and Qing Dynasties of the Palace Museum, Beijing: Zhonghua Book Company

- Reynolds, Douglas (2006), China: 1898-1912: The Xinzheng Revolution and Japan (translated by Li Zhongxian), Nanjing: Jiangsu People's Press

- Sakamoto Taro (1992), General Introduction of History of Japan (translated by Wang Xiangrong et al.), Beijing: The Commercial Press

- Sanetou Keishud (1983), History of Chinese People Studying in Japan (translated by Tan Ruqian et al.), Beijing: Joint Publishing Company

- Wang Jian (2001), The Law Education in Modern China, Beijing: China University of Political Science and Law Press

- Wang Xiaoqiu, Oraba Shu (eds.) (1996), Outline of History of Chinese and Japanese Cultural Exchange - History Volume, Hangzhou: Zhejiang People's Press

- Western Laws Introduced into China: Foreigners and the Reform of Chinese Law in Modern Times (2001), Beijing: China University of Political Science and Law

- Yan Shaodang, Minamoto Kyōen (eds.) (1996), Outline of History of Chinese and Japanese Cultural Exchange - Ideology Volume, Hangzhou: Zhejiang People's Press

- Zhu Shoupeng (ed.) (1958), Records of Imperial Government in Guangxu Period, Beijing: Zhonghua Book Company

- Zhu Weizheng, Long Yingtai (comp.) (2000), Records of Old Dreams of the Reform: the »Self-Reform« Movement of China a Hundred Years before Wuxu, Beijing: Joint Publishing Company 